\title{
TURKEY'S PREDICAMENT IN THE POST-COLD WAR ERA
}

\section{Meltem Müftüler-Bac}

The ultimate objective of the modern Turkish republic was to be recognized as a European state. The Cold War structures enabled the realization of that goal. Turkey's Europeanness was defined according to its geostrategic position; it became a reliable ally for the West as a buffer state against the former Soviet Union. The disappearance of the Cold War structures have brought the importance and suitability of Turkey for Europe into debate. In order to secure its position in the European order, Turkey had to redefine its policy formulations, as determined by Turkey's Eastern connections (whilst attending to the essentially non-Western elements in Turkey such as Kurdish nationalism and Islam). This article analyses how the new Turkish foreign policy in the Middle East, which is motivated to secure its place in Europe, brings out the non-Western elements in Turkey. The aim is to determine the extent to which such changes will shape Turkey's futures. Copyright (C) 1996 Elsevier Science Ltd

1989 was a year of fundamental change in the global order. The dismantling of the Soviet Union and the fall of the Berlin Wall caused breakthrough changes in the international arena. The face of Europe has changed with the transition of the Eastern European countries from communist states to democracies and the emergence of a united Europe under the umbrella of the European Union. A new Europe is under construction. The dissolution of the post-World-War-II bipolar balance-of-power system leads to a search for new policies among the states which are inevitably affected by the uncertain environment of the post-Cold War era.

This article focuses on the impact of the end of the Cold War on Turkey's foreign policy. The hypothesis is that the modifications in Turkish foreign policy in response to the precarious external environment are becoming increasingly influential in shaping Turkey's futures. The aim is to analyse the changes in Turkish foreign policy specifically towards the

Meltem Müftüler-Bac is Assistant Professor at the Department of Political Science, Facully of Adruinistrative Sciences, Bilkent University, Ankara, 06533-Turkey (Tel: +90 312 266 4137; fax: +90 312266 4960; email: meltem@bilkent.edu.tr). 
Middle East in the post-Cold-War period. A latent objective is to assess whether these policy changes are hampering or improving Turkey's position in Western security arrangements. It is, of course, beyond our scope here to predict what Turkey's futures will hold, but the article will hopefully provide some insights to the reader as to the security dilemmas confronting Turkey in the post-Cold-War order and the available options to deal with these dilemmas.

During the Cold War, Turkey's place in the global order was determined by its geography. Turkey since 1952 has served as a 'south-eastern bastion of the NATO alliance', but the end of the Cold War reduces the need for a defensive bastion. ${ }^{1}$ The disappearance of the communist threat raised certain question-marks in Western minds as to the importance of Turkey as a security partner since the major raison d'être for Turkey's incorporation into Western security systems - to deter the Soviets - has disappeared. The dismantling of the Soviet Union has caused a reformulation of foreign policy objectives both in Turkey and in the Western alliance as regards Turkey's position in Western security. Thus, Turkey is looking for a new role for itself which is again defined by its geostrategic position, this time, however, with respect to its central location amidst areas of potential instability.

In 1995, the spectre of chaos haunts the former USSR, numerous civil wars have broken out and a rampant nationalism has surfaced in Central and Southern Europe. ${ }^{2}$ Against such a background, Turkey's volition for stability has become more profound. Its role has gradually modified from being a buffer state to one defined as an 'island of stability'. To quote Marc Grossman, the US ambassador to Turkey, 'Turkey lives in a neighborhood that is a 360 degrees challenge' and Turkey's place has changed from being a 'wing' state to a 'front' state for Europe and the USA. The perception among Turkish policy makers is that Turkey is the only country in the region that can defend and represent the interests of Europe. Turgut Özal, the Turkish prime minister between 1983 and 1989 and the president from 1989 until his death in April 1993, declared on a number of occasions that 'The 21 st century will be the century of the Turks'. Tansu Ciller, prime minister since 1993, has claimed that, 'If Turkey is transformed into a "super"economic power in the region', it would contribute to political and economic stability in Europe. She tried to mobilize support for her policies from the European governments and the USA by claiming that, 'If Turkey fails, peace will fail in Europe'. The assumption in the Turkish foreign ministry, for example, is that a stable Turkey will have the capacity to become an influential player in Middle Eastern politics and affect the futures of European relations with the Middle East. Onur Oymen, Undersecretary of the Turkish foreign ministry, has claimed that, 'Joining the EU would make nol just another member but one of the most important members of Western Europe' ${ }^{3}$ Underlying all these claims is the perception among the Turkish policy makers that Turkey's importance for the West has increased due to its eastern connections.

Questions about Turkey's place in the new European security arrangements also lead to questions concerning Turkey's European credentials. In its search for a new role in European security, Turkey opened itself to various challenges that have been repressed since modern Turkey was founded. What has been formerly defined as a secular, national, European state is openly challenged by Islamic fundamentalism, Kurdish nationalism, and Turkey's European status is ferociously debated both in Europe and in Turkey. Thus, the reformulation of Turkish foreign policy objectives in the post-Cold-War era also brings a reformulation of Turkish identity, an unenviable task by all means. 
Turkey's role in Middle Eastern security in the post-Cold-War era has gained preeminence basically because the end of the Cold War meant that Turkey can no longer depend on its position with respect to the strategic rivalry between the USA and the former USSR. The new justifying factor for Turkey's place in European security is now the uncertain and unstable environment left by the political vacuum of the Soviet Union's demise. Turkey is surrounded by areas of instability: to the north east, there is the Caucasus and the Armenian-Azerbeijani dispute over Nagorno-Karabagh region; , to the north west, there is the Bosnian crisis, and to the south, there is the Middle East. Contrary to what may have been expected, the article demonstrates that Turkey still occupics a central place for Western security. The only drawback in Turkey's emerging position is that the new areas of conflict surrounding Turkey automatically bring Turkey's non-Western elements to the front stage. Since 1989, Turkey's strategic significance is once again being assessed chiefly in its Middle Eastern context. ${ }^{4}$ Turkey's role as a regional stabilizer and arbiter has been emphasized for the futures of the Middle Cast. The US Assistant Secretary of State, Richard Holbrooke claimed that, 'Turkey is replacing Germany as the cutting edge of Europe', and described Turkey as the American government's 'new European front'.

The Middle East is greatly affected by post-Cold-War developments. Events such as the Gulf crisis of 1990-91 demonstrated that even if the superpower conflict has ended, the Middle East is still a prime source of global instability. ${ }^{5}$ The uncertainty surrounding the area is further accentuated by the Arab-Israeli peace process that began in October 1991 with the Madrid Framework. The Middle East region has always been troubled by historically rooted hostilities, lack of effective, legitimate governments and border problems, and its future is going to be further plagued by issues such as water politics, the Kurdish problem, oil scarcity, and a lasting peace for Israel and the Palestinians. States located in this highly volatile region are therefore in search of new strategies to adjust to the changing security needs. Turkey's role in Middle Eastern security, the future of the Kurds and the Arab-Israeli peace process will markedly shape the futures of the Middle East as well as that of Turkey.

An important component shaping Turkey's position in the emerging world order is the new relationship between Turkey and the European Union. On 6 March 1995, Turkey and the EU signed a customs union agreement which highlights Turkey's importance for Europe not only in terms of security but economics as well. The customs union is composed of two parts, eliminating tariff barriers to trade between Turkey and the EU and Turkey's adoption of the Community's Common External Tariff (CET). Turkey's adoption of CET will either cause a trade diversion or trade creation effect on Turkey's trade with third parties depending on the level of the pre-customs union tariff imposed by Turkey to imports originating from third parties. When the customs union agreement is put into operation, Turkey will have access to the European market under practically the same terms with the members of the EU. The customs union with the EU would also transform Turkey into an economic platform for the Middle Eastern countries that are exporting to the EU. Closer economic integration with the EU will have spillover effects on Turkey's relations with the Middle Eastern countries and the Central Asian republics with which Turkey has close economic ties. Thus, trade between Turkey and the Middle East will automatically be affected by the customs union of 1 January 1996 which would influence Turkey's futures in the Middle East and the EU, as a bridge between the two.

Central to the hypothesis of this article is that in the post-Cold-War era, the immediate 
dilemma that Turkey faces concerns its identity, whether it is defined and accepted as a European or a Middle Eastern state. Turkey's 'cultural dilemma' will determine its futures in both external and internal affairs. In its external affairs, it means that a century-old inhibition - the belief that following an active Middle Eastern policy will bring out the non-Western elements-must be overcome. In its internal affairs, the dilemma can be overcome only with the recognition of the existence of subsystem groups such as those in favour of religious fundamentalism and Kurdish separatism, yet these two are perceived to be the basic threats to the survival of the Turkish republic. This dilemma is, for example, partly the reason why the religious sentiments in Turkey have boosted over the past five years. The pro-Islam Welfare Party, under the leadership of Necmettin Erbakan, is gaining support among the electorate because they suggest going back to the roots, the Islamic traditions of Turkey, such a claim appeals particularly to the economically and culturally alienated population in the major cities. During the 1990s, there is an increasingly felt need in Turkish society for a consensus that reconciles its divergent segments and for a reformulation of the Turkish identity.

Thus this article proposes that the futures of Turkey will be shaped by basically three major factors: (1) the cultural dilemma of Turkey; (2) instability in the Middle East and Turkey's position in the Middle Eastern subsystem of states, (3) Turkey's new and closer ties with the European system of states, as symbolized by the EU. These three factors are not, however, mutually exclusive, they should be perceived as interacting vectors.

\section{Turkey: the odd man out in the Middle East}

Bernard Lewis quoted Field Marshall Slim as saying, 'Turkey is the only European country in the Middle East' ${ }^{6}$ Turkey has always been the odd man out in Middle Eastern politics. Turkey is classified as the only secular Muslim state that is ruled by norms of democratic conduct and free market economy. Turkey's place in Middle Eastern politics, therefore, is determined by its special status, it is Muslim yet not Arab, it is geographically located in the Middle Eastern region yet it is a member of almost all European organizations. Turkey is not a part of Muslim Arab culture but neither is it a part of Christian European culture. Thus, it is small wonder that Turkey is defined as a torn country by Samuel Huntington ${ }^{7}$ in his famous article 'The clash of civilizations'. A torn country is:

their leaders typically wish to pursue a bandwagoning strategy and to make their countries members of the West, but the history, culture and traditions of their countries are non-Western. The most obvious and prototypical torn country is Turkey... while the elite of Turkey has defined Turkey as a Western society, the elite of the West refuses to accept Turkey as such. ${ }^{8}$

Traditional Turkish foreign policy has aimed at gaining acceptance from the West for Turkey's Europeanness. Turkey's place in Europe is unique because it carries elements of both cultures, and to clarify Turkey's position in any subsystem of states is, therefore, problematic. The end of the Cold War has made such a clarification more urgent because now Turkey is trying to formulate a new foreign policy in an attempt to adjust to its turbulent external environment.

When the modern Turkish republic was created, the assumption was that the ideal Turk was to be European in outlook, and Turkey's place was among the European states. The transformation of the society into a European one was imposed from above, the traditionalist tendencies which favour close links with the Middle Eastern states and 
preserving the Islamic identity of the state were repressed. The formulation of a modern Turkish identity was partly the reason for the move away from the Middle Eastern character of Turkey. The traditionalist elements of the Turkish identity were closely sealed in a Pandora's box which was reopened at the end of the Cold War.

Since the dissolution of the empire, the relationship between Turkey and the states of the Middle East has become more complex, formal and differentiated. ${ }^{9}$ During the period from the creation of the Turkish Republic in 1923 to the end of World War II, Turkish foreign policy towards its Middle Eastern neighbours was one of non-involvement. In the post-World-War-1l period, Turkey strove to gain entry into the newly emerging Western security organizations and its foreign policy towards the Middle East has followed its allegiance with the West. Nevertheless, the Turkish government tried on a number of occasions to convince its Middle Eastern neighbours that its alliance with the West did not pose a threat to its relations in the Middle East. The best illustration for that would be Fatih Rüstü Zorlu's speech at the Bandung Conference in 1955. Yet, Turkey acted like a European state located in the Middle East rather than a Middle Eastern state, and in that respect Turkish foreign policy was similar to Israel.

In 1945, the newly emerging Western security organizations had one ultimate aim, that is to stop Soviet expansionism and aggression, and Turkey's role was defined accordingly: to act as a buffer state against the Soviet Union. The Turkish government, in return, sought recognition within the Western camp for two reasons, first to gain the status of a European power, and second to deter the Soviets from demanding territorial concessions. Turkey was accepted into such Western organizations as the OECD (then the OECC) in 1948, the Council of Europe in 1949 and NATO in 1952 which gave Turkey the long aspired stamp of approval for being a European state. The decisive culmination of this incorporation into the European ranks was the Ankara Agreement of 1963 signed between the EEC and Turkey for associate membership. The search for Turkey's identity as defined by its Europeanness seemed to be finally over now that it was officially 'part of Europe', as declared by Walter Hallstein-the President of the European Commission-in 1963.

During the Cold War years, Turkish foreign policy towards the Middle East was determined by Turkey's place in the Western alliance. However, developments in the 1960 s and the 1970 s caused Turkish policy makers question the virlues of the alliance. The factors which caused a shift in Turkish policy towards its Middle Eastern neighbours were, first, the question of support for the Turkish position in the Cyprus crisis, and second, the emerging economic interests of Turkey in the Middle Eastern markets, both as a net importer of crude oil and as an exporter to the Middle Eastern countries. The changes in Turkey's policy towards the Middle East can be observed in the 1970s, when Turkey voted in the United Nations for all the UN resolutions for the Palestinian issue in 1974, it became a member of the Islamic Conference in 1976, and it recognized the Palestinian Liberation Organization (PLO) as the sole representative of the Palestinian people in 1979.

Turkey recently abandoned its traditional non-interventionist policy among the other Muslim countries and instead strived to act as a regional power. I urkey's foreign policy during the Cold War has been remarkably consistent, with primary allegiance to the West. The post-Cold-War era, however, is leading to a search for new policy initiatives for Turkey, but again the ultimate aim is to secure its position in the newly emerging Western order and to be accepted as part of Europe. The futures of Turkish foreign policy in the Middle East are evolving around four interacting vectors-security in the Middle East, the Kurds, the politics of water and the role of Islam. 


\section{Security in the Middle East: the Gulf crisis}

The breakthrough change in Turkey's foreign policy towards the Middle East came with the Gulf crisis of 1990-91. The Turkish government under President Turgut Özal's leadership had pursued an active policy supporting the allied coalition against Iraq, and broke away from its traditional non-involvement stance. The crisis had a significant impact on Turkey's relations with the Middle East. Ankara responded to the Iraqi invasion of Kuwait by assuming a central role in the allied coalition. This was a major break from decades of established Turkish policy concerning non-involvement in Middle Eastern conflicts. Turkey's active role in the crisis was formulated by President Turgut Özal and reflected his efforts to redefine Turkey's role in regional politics. The Gulf crisis erupted at a time when Turkish perceptions about the restructuring of the European security system were tinged with considerable pessimism and concern. ${ }^{10}$

Turkey's participation in the multinational coalition against Iraq carried significant weight because first, the oil pipelines passed through Turkey, specifically the Kerkuk-Yumurtalik pipeline on which Iraq depended for about half its oil exports, and second, Turkey was an exporter of consumer goods to Iraq and a transit way for goods coming from third states.

The Gulf crisis became an important turning point for Turkey's relations with the West. It quickly became an issue involving both the Middle East and the Western relations of Turkey and the policies developed in Ankara in one sphere could not help but have a major impact on those in the other. ${ }^{11}$ The Gulf crisis was important to analyse the strength of Western security because it revealed how the European countries can be harmed by a turmoil in the Middle East, and the extent to which the Europeans were tied to stability in this region. ${ }^{12}$ Turkey's standing during the crisis proved both its solidarity with the West to overcome aggression and also that Turkish cooperation to achieve stability, order and peace in the Middle East region carries vital importance for the new European order.

The Gulf crisis demonstrated the importance of Turkey as a security partner for the West, and thus rendered void the above arguments about whether Turkey is still needed in the Western alliance. As for the Turkish government, the crisis demonstrated that Turkey is surrounded by a group of potentially unstable and hostile states, the actions of which are highly unpredictable in the uncertain environment of the post-Cold-War era. Thus, its place in the Western alliance, therefore, is important for deterrent purposes.

The Gulf crisis underlined Turkey's importance as a regional power. At the same time, however, the crisis worked in the counterdirection by pointing out to a potential weakness in Turkey, namely the ongoing Kurdish problem. To bring the Kurdish problem into the limelight of international politics was an unintended consequence of the Gulf War, yet it revealed that 'the persistence of a violent domestic conflict will undermine Turkey's role as a stabilizing influence in the regions in which its interests and those of its Western allies coincide. $^{13}$

\section{The Kurds}

One of the pressing problems facing Turkey today is the growing sentiments of Kurdish nationalism, which is more markedly felt in Turkey's both internal and external politics. The Turkish strategy in handling the Kurdish problem is increasingly determining its relations with the Middle Eastern and European states: 'Saddam Hussein's occupation of 
Kuwait on August 2, 1990 created major problems for Turkey with regard to its own Kurds'. ${ }^{14}$ The Gulf crisis underlined the urgency of the Kurdish problem for future stability in Middle Eastern politics. For example, during the crisis, President Özal had made it clear that Turkey's participation in the allied coalition would be bound to the condition that no separate Kurdish state was to emerge in Northern Iraq. Nevertheless, the plight of the Kurds in the region had attracted international public opinion to the issue and pressed the Turkish government to recognize some of the demands of the Kurdish community. Turkey's relations with the European Union, for example, is increasingly determined by its approach to its Kurdish population.

When the Turkish republic was founded in 1923, the state elite recognized the existence of only the religious communities in Turkey-the Jews, Armenians and the Greeks-as minorities under the 1923 Lausanne Treaty. The Muslim groups, whether they were Kurds or Alevis, were not recognized as minorities. This at the time was perceived as a necessary measure for the ongoing nation-building process. In 1974, a group of Kurdish nationalists organized under Abdullah Öcalan's leadership formed the Kurdish Workers' Party (PKK), the main terrorist organization in Turkey. The clashes between the Turkish state and the PKK reached a peak in the 1990s.

The Kurdish problem is not, however, confined to the borders of Turkey. The Kurds are dispersed in the area with vast majorities living in Syria, Iraq, Iran and to a certain extent in Russia. The Kurdish insurgency gained momentum after the Gulf crisis with the hopes of creating a federated Kurdish state in Northern Iraq. Turkey's future relations with its Middle Eastern neighbours with borders in the south east such as Syria, Iran and Iraq, are increasingly determined by the Kurdish problem.

In March 1995, the Turkish army intervened in Northern Iraq, Operation Steel, in an attempt to fill the political vacuum left by the Gulf War. The Turkish government statement released on 20 March 1995 by the Information Office of Foreign Ministry is as follows: 'PKK, due to lack of authority in Northern Iraq, has intensified its activities against the Turkish Republic from this region. Aimed at protecting the lives and security of innocent people, the operation will be of limited duration and the forces involved will be withdrawn immediately following the elimination of the targets'. The Prime Minister, Tansu Ciller, in her 'Address to the Nation' on 25 March 1995 declared that 'We will put an end to terrorism'.

General Orhan Yoney of the General Staff of the Turkish Armed Forces declared 'Turkey's aim is to clear areas adjacent to its border where Iraqi Kurdish groups are no longer in authority of a PKK presence and thus prevent an increase in terrorism inside Turkey'. The aim is to stabilize and ncutralize the PKK influence. Hikmet Cetin, a former foreign minister, the leader of the Republican People's Party and the deputy prime minister at the time, has summarized the aims of the intervention as: (1) to destroy PKK's logistic and military bases in Northern Iraq; (2) to safeguard civilians within the region where the operation is conducted; and (3) to ensure that Turkey would withdraw, and that this is a limited intervention.

A latent objective, however, is to demonstrate Turkey's power in the area where the two Iraqi Kurdish groups, the Kurdish Democratic Party (KDP) under Massoud Barzani's leadership and the Patriotic Union of Kurdistan (PUK) under Jalal Talabani's leadership, are the dominant political forces. Ankara has denied, however, that a buffer zone would be created in the area even though some prominent politicians such as Bulent Ecevil, the leader of the Democratic Left Party, has favoured the idea of a buffer zone. Ciller claimed 
that the operation was conducted in keeping with the 'international law' giving Turkey the right of hot pursuit. During the almost two-month operation, which began on 20 March and ended on 5 May a substantial amount of weaponry and ammunition was captured. The spokesman of the Turkish Armed Forces, General Dogu Silahcioglu, declared that 'when it is considered that these were used against the citizens of Turkey, it once again becomes clear how just and how successful the operation has been'. ${ }^{15}$

Not everybody shared the same idea. Within the Turkish Parliament, a small group of parliamentarians questioned the way the decision to intervene was taken and presented the parliament with a 'suggestion' ${ }^{16}$ for a 'general discussion' in the Turkish Grand National Assembly about the intervention which was decided on by the Turkish armed forces. The inconsistent declarations of the prime minister Tansu Ciller, President Suleyman Demirel, deputy prime minister Hikmet Cetin and the foreign minister Erdal Inonu about the withdrawal date of the armed forces from the area demonstrated the lack of coordination between various branches of the government and that the real decision maker is the Turkish armed forces with the upper hand belonging to the Chief of Staff, General Ismail Hakki Karadayi. The civilian authorities bowed to the wishes of the military. This becomes particularly evident when one considers that the operation was not discussed in advance in a cabinet meeting or in the parliament. ${ }^{17}$

Outside Turkey, the Middle Eastern neighbours agitated by the Turkish action were mainly the Iranian, Iraqi and Syrian governments. This disturbance was not eased by the declarations of Prime Minister Tansu Ciller, that 'Turkey will carry out further incursions into Northern Iraq if it considers this necessary'. The agitation reached a peak when President Suleyman Demirel implied that the border between Turkey and Iraq should be redrawn, thus reviving the almost century-old question of Musul. Turgut Özal also is known to make similar claims on the oil fields in Northern Iraq during the Gulf crisis. Nevertheless, the Turkish position is such that Ankara is in favour of the territorial integrity of Iraq. The Turkish Foreign Ministry firmly states that no such changes are on the table with the Iraqi government. It is interesting to note the reaction of the USA to the operation. US Assistant Secretary of State, Richard Holbrooke, announced that the operation did not violate international law and he claimed that, 'It is in the self-defence of Turkey, the PKK is a terrorist organization operating across an international border and we understand that'. The only condition imposed by the USA was the guarantee from the Turkish government that the intervention was to be 'limited in scope and duration'. The perception of the US government was that, 'This is an operation conducted by a legitimate, democratic government and a close ally of the West against a brutal terrorist organization. Turkey remains an important adjunct of Europe and a key member of the Atlantic Alliance. It remains our friend in a troubled region and deserves our support'. ${ }^{18}$

The most severe reaction came from the European states. Germany, Norway and Holland imposed an arms embargo on Turkey. During the EU-Turkey Troika meeting on 23 March, with the German, French and Spanish foreign ministers (the previous, present and next-term chairmen of the EU presidency) one of the topics discussed was Operation Steel and its possible impact on the Turkish-EU customs union. There was a danger that Turkey's customs union agreement with the EU to be ratified in 1995 by the European Parliament may be jeopardized because of Operation Steel. The European Parliament passed resolutions against Operation Steel and on 26 April 1995, the Parliamentary Assembly of the Council of Europe has decided that if Turkey does not withdraw from Northern Iraq in a period of two months and if it does not restore 
democratic practices to its Kurdish population, Turkey's membership in the Parliamentary Assembly may be suspended. The Turkish response to the European reaction can be best summarized by Hikmet Cetin, the deputy prime minister, who accused the Europeans for being responsible for creating the security vacuum in Northern Iraq which enabled the PKK to set up bases there, creating the need for the incursion. The bottom line is that the Kurdish problem has become the most important issue that shapes Turkey's futures in Europe and in the Middle East.

\section{Water as a source of power}

A third issue that influences Turkey's futures in the Middle East is the 'politics of water'. Turkey and Iran are the only two countries in the Middle East that are relatively self-sufficient in water resources. Two major rivers, Euphrates and Tigris, originate in Turkish territory and they flow into Syria and Iraq, the downstream countries. Turkey is in a strategically strong position as the only country in the Middle East which enjoys abundant groundwater resources. ${ }^{19}$ Since the early 1980 s, the water problem has become one of the foreign policy issues in Turkey due to two reasons: (1) the GAP project (the building of a dam in southeast Anatolia) using the water resources of the two rivers, Euphrates-Firat and Tigris-Dicle; (2) the Turkish peace pipeline project.

The GAP project is liable to cause tension between Turkey, the upstream country on the one hand and Syria and Iraq, the downstream countries, on the other. Syria was the first country that tried to exploit the water resources in the area for hydroelectricity but due to low levels of water flow it could not effectively do so. Turkey's advantage over Syria and Iraq with respect to the Euphrates and Tigris rivers is that about $90 \%$ of the water from these rivers is drained from Turkish soil. Since natural resources are an important element of a country's power in dealing with other states, Turkey's water resources give power to Turkey when it is dealing with the Middle Eastern countries.

The Turkish government has been using water politics against Syria as a bargaining tool in response to the alleged Syrian backing of the PKK. For example, water retention has been used as a threat by the Tansu Ciller government against Syria in December 1993 in retaliation for Syrian support of the Kurdish separatist movements against Turkey. The Kurdish issue hampers the already not so amicable relations between Turkey and Syria because of the alleged backing of the separatist Kurdish organization, the Kurdish Workers' Party (PKK) by Damascus. Since 1992, there have been ongoing negotiations between the Turkish government and the Syrian government over the protection of PKK supporters and the PKK leader, Abdullah Öcalan, by the Syrian government:

Turkey suspects that the increasingly active support that Syria has been giving to the PKK terrorists is intended to harm the Turkish development plans and to put pressure on Turkey to meet their demands for a greater share of the Euphrates and Tigris rivers. ${ }^{20}$

The second aspect of the politics of water is the peace pipeline project which will use the water resources from two other Turkish rivers, Ceyhan and Seyhan, that rise in central Anatolia. The project aims at transporting water from the relatively water-abundant region of eastern Turkey to the countries in the Gulf and Levant by two water pipelines-one would go through Syria and Jordan ending up in Mecca; the Western pipeline and the other would go from Kuwait to Oman, the Culf pipeline. ${ }^{21}$ In addition, there are ongoing negotiations for the sale of Manavgat water from Turkey to Israel. The role of water is also 
important in the multilateral track of the Middle Eastern peace process in which water is one of the five working groups. In their joint invitation to the Madrid Peace Conference in October 1991, President Bush and President Gorbachev listed 'water' as one of the issues that was crucial for peace and stability in the region. ${ }^{22}$ Thus, Turkey's power in the peace process can be increasingly assessed with respect to water.

Since it has become fashionable to say that the next war in the Middle East could be fought over water, ${ }^{23}$ Turkey, by providing cheap water on a reliable basis, will decrease the tension around the allocation of this scarce resource in the region. Water is becoming an essential component-both as an attribute and as a symbol-of political power in the Middle East. ${ }^{24}$ Turkey's water resources would increase the Middle Eastern countries' dependency on Turkey for water which, in turn, would promote Turkey as a regional power in the area. Therefore, the sale of water and the peace pipeline project fall perfectly into the greater scheme for Turkey in its aspirations towards playing a more prominent role in the neighbouring region.

\section{The role of Islam}

The final issue for the futures of Turkey are the growing tendencies towards Islam. Islam is becoming an important element in Turkish politics as it comes out of the closet. An important factor causing the rise of Islam in Turkey is said to be Turkey's growing ties with the Middle East. In the attempt to diversify Turkey's foreign policy, Turkish politicians such as President Kenan Evren and Turgut Özal have experimented with ties in the Islamic countries. Kenan Evren, for example, became the first head of state ever to attend and preside at a meeting of the Organization of the Islamic Conference (OIC) in 1984.

The main political expression of Islam in Turkey is the Welfare Party, the successor of the National Salvation Party, under Necmettin Erbakan's leadership. The WP's votes have increased over the past five years, and it finally culminated in their relative success in the March 1994 local elections in which they received $18.4 \%$ of the national vote and the mayors of the two main cities-Ankara, the capital city and Istanbul, the business centre-are now the representatives of the Welfare Party. The results of the March 1994 elections 'simultaneously placed the country's most cosmopolitan city and its national capital and symbol of the secular order in the hands of a Muslim Party'. ${ }^{25}$ According to Mango, in the era where socialist ideology has lost its grip over the people, 'Islamism is the only ideology that challenges the political system', ${ }^{26}$ which of course makes the WP the only real opposition party in Turkey, since all other parties are centre-oriented and similar in their party platform. Turkey's external relations and its internal problems seem to interact in giving religious sentiment a boost. There is a strong connection between economic marginalization, alienation and the steady growth of Islamic consciousness. ${ }^{27}$ As the Turkish government fails to cope with the pressing demands of the population for better services and economic recovery, the already marginalized groups and the urban poor increasingly support the Welfare Party. The expanding ties with the Middle East since mid-1980s also helped the increase in this sentiment. The growing influence of Islam would seem obvious: there is now a tendency in the West to consider that the threat of 'communism' has been replaced by the threat of 'militant Islam'.

Thus, many people in the West are emphasizing the role of Turkey, as the only secular, European oriented country that would act as a buffer to militant Islam. 'Like the "Red Menace" of the Cold War era, the "Green Peril" - green being the colour of 
Islam-is described as a cancer spreading around the globe undermining the legitimacy of the Western values and threatening the security of the Western nations ${ }^{\prime} .{ }^{28}$ It is ironical that as Turkey increases its ties with the Middle East, it opens up to Islamic influences which jeopardize the secular Turkish state's survival, yet it is perceived by many in the West as the bastion against the Green Peril, as it was once perceived as the bastion against the Red Menace.

\section{Conclusion}

This article has attempted to demonstrate that Turkey has diversified its foreign policy and established new ties with the Middle East as a trump card for its standing in Europe in the post-Cold-War era. ${ }^{29}$ An unexpected development of the new Turkish foreign policy was that it brought various tendencies in Turkey out of the closet, thereby threatening the officially defined identity of the Turkish state.

Turkey's futures and its foreign policy in the Middle East are formulated over four interacting vectors: security in the Middle East as illustrated by the 1990-91 Culf crisis, the Kurdish insurgency, the rise of Islam and scarcity of water. With respect to these issues, Turkey acts like a regional power in its attempt to carve out a new identity that would clarify its position in the emerging European order. Thus, Turkey's aspirations in Europe remain intact in the post-Cold War era.

The Turkish bid to become a regional power is not just restricted to its standing in the Middle East. Turkey, since 1989, has been involved in other regions in its perimeter such as the Black Sea zone, the Balkans, the Caucasus and Central Asia. The futures of Turkey hold these new arenas for increased Turkish influence. The Turks, under Özal's leadership, began to explore other means of enhancing Turkey's political and economic role, such as the establishment of a Black Sea economic cooperation scheme. The famous quote of Özal, a Turkish sphere of influence 'from the Adriatic Sea to the Chinese Wall' has alarmed many who neighbour Turkey. The exploration still continues after Özal's death. For example, Turkey's main role in the Central Asian region has been to decrease the negative effects of rapid change and facilitate a smooth transition from Soviet rule to statehood. Turkey's role is becoming more economic through the economic network of the BSECA and ECO-the Economic Cooperation Organization of which Turkey, Iran, Pakistan and the Central Asian republics are members. What the future holds, then, is an all-encompassing network of economic relations in the east, and Turkey in between the EU and Central Asia. A latent Turkish objective is to act as a leader in linking Central Asia and the EU through lechnical, economic and financial assistance. Turkey's bid towards a leadership role in the Central Asian republics is increasingly met with opposition from Russia and Iran. The triangular competition involving who will be more influential in this region will get fiercer in the near future when construction of the pipelines to transport oil and natural gas from the republics to Europe begins. For an effective Turkey, the USA and the EU should back Turkey against the influences of Iran and Russia.

Thus, Turkish foreign policy in the post-Cold-War era has been largely determined by this desire for regional leadership. The motive behind this bid towards regional power was largely the fear of losing ground among the European states now that the Soviet danger was gone. By pointing out the potential problem areas in the Middle East which continue to threaten European security, Turkey can still secure its position as an indispensable ally of the West. Post-Cold-War Turkish-European relations are shaped with respect to Turkey's 
position in this unstable region and to the extent to which the European states can rely on Turkey as an agent of stability. For example, in May 1992, one of the MEPs of the European Parliament (EP), Raymonde Dury, presented a report to the EP stating that, 'In future, Turkey will play an ever more important, even a decisive political role in an especially endangered region', ${ }^{30}$

In the post-Cold-War period, the Turkish governmental leaders are convinced that it is not enough for Turkey to enjoy stability within its own borders. Turkey will not be able to ensure, or safely enjoy, its own stability unless international order also extends to its neighbours. ${ }^{31}$ How Turkey helps to promote stability in the region where it is located remains to be seen. Turkey's role in Middle Eastern stability becomes more profound as the peace process which began in Madrid in October 1991 unfolds. Central to a viable, lasting peace in the Middle East both between the Israelis and the Arabs and the Arabs themselves is the multilateral track. Within the multilateral track, Turkey's participation is essential in the forums on water, regional cooperation and economic development. The Arab-Israeli peace process, then, is an important arena to be exploited by Turkey in this quest for stability.

The integration into the Western alliance has helped Turkey to deal with most of its internal issues, such as Kurdish nationalism, Islamic fundamentalism and respect for human rights. It appeared that the end of the Cold War had reopened the question of Turkey's basic political and cultural orientation. ${ }^{32}$ As Turkey becomes more actively involved in Middle Eastern politics in an effort to redefine its position for European security, it opens up to various challenges that threaten its official ideology:

Turkey has fallen victim to the many of the tensions of the region. The challenge of integrating the various ethnic and religious components of Turkish society on a basis of mutual acceptance rather than assimilation has, in turn, influenced the debate over foreign policy objectives in the mid-1990s. ${ }^{33}$

Those actions which Turkey undertakes to become a regional power or to increase its power, such as its involvement in the Gulf crisis and the cooperation schemes for water, also seem to operate in a counterdirection, making Turkey weaker. This seems to be the predicament which Turkey cannot escape in post-Cold-War international politics.

The main obstacle facing Turkish policy makers is that the more the Turkish government becomes involved with its immediate neighbours, the more its own internal problems come to the fore. Turkey's bid towards regional power status is opening up the Pandora's box which was sealed in 1923. Turbulence in the Middle East as shown by the Kurdish problem and the rise of Islam is now increasingly felt in Turkish politics; they became the parameters for post-Cold-War Turkish domestic politics as well. For example, with respect to the Kurdish issue, the Turkish government has no option but to recognize the Kurdish population's cultural claims. A number of steps have already been taken in that direction, the use of Kurdish language, the right to broadcast and publish in Kurdish have been allowed since 1992. In March 1995, for the first time in Turkey, the Kurdish holiday, Newruz-New Day, has been officially celebrated and P M Ciller has declared it to be a national holiday of the Turkish republic. President Demirel came up with the concept of 'Constitutional citizenship' as a political solution to the Kurdish issue. The idea of constitutional citizenship was perceived to be that a person living within the borders of the Turkish republic is considered a citizen of the Turkish Republic regardless of whether he/she is an ethnic Turk, this idea bringing a redefinition of the concept of citizenship in Turkey. A very likely scenario for the future of the Kurds is that there will be closer 
cooperation between Turkey and the Kurds in Northern Iraq under KDP and PUK. President Demirel has claimed that, 'A strong and functional cooperation should be established with the local administration in Northern Iraq to secure the Turkish-Iraqi border'. ${ }^{34}$

The futures of Turkey will increasingly be determined by Turkey's position between Europe and the Middle East. The end of the Cold War opened up new economic opportunities for Turkey, so a closer integration between Turkey and the EU on the one hand and of Turkey and the Middle East on the other has become possible. However, these opportunities can be effectively used only if Turkey puts its own political house in order.

For Turkey to come to grips with its hidden, repressed tendencies, there is a need for a social consensus; unless such a consensus is reached, Turkey's relations with the EU and the West will be hampered. The most important obstacle Turkey faces in its relations with the EU is the process of democratization and respect for human rights. In addition, the US support of Turkey's customs union with the EU and of Turkey's fight with PKK terrorism is going to be determinant of Turkey's futures. The US position is that 'A EU with Turkey is more promising to the US and Turkey will be even more valuable when it deepens its economic relations with the EU'. ${ }^{35}$ Warren Christopher has claimed that 'Turkey is on a strategic crossroads, thus both the US and the EU have major interests in supporting a democratic Turkey'. ${ }^{36}$ Ciller has claimed that 'Modern Turkey is a part of Europe' and that the customs union with the EU has become a 'door for more security'. Yet, for that door to remain open, Turkey has to become more democratic, in line with European standards. The futures of Turkey in the post-Cold-War era still seem to be with the European system of states, but the future is also shaped by Turkey's 'eastern connections' and its capacity to create a new social consensus.

\section{Notes and references}

1. Andrew Mango, Turkey: The Challenge of a New Role, Washington Papers No 163 (Washington, DC, 1994), page 110

2. Philip Lawrence, 'European security: from euphoria to confusion', European Security, 3(2), 1994, page 219.

3. Turkish Daily News, 17 June 1995.

4. Bruce Koniholm, 'Turkey and the West', Foreign Affairs, 70(2), 1991, page 34.

5. William Hale, 'Turkey, the Middle East and the Gulf crisis', International Affairs, 68(4), 1992, page 679.

6. As quoted by Seyfi Tashan, 'Current Turkish policy in the Middle East', in George Harris (editor), (A Report of A Heritage Foundation Conference, 1984), page 37.

7. Samuel Huntington, 'The clash of civilizations', Foreign Affairs, 72(3), 1993, page 42.

8. Ibid, page 42 .

9. Philip Robins, Turkey and the Middle East (London, Pinter, 1991), page 17.

10. Sabri Sayari, 'Turkey: the changing European security environment and the Gulf crisis', The Middle East Journal, 46(1), 1992, page 10.

11. Robins, op cit, reference 9 , page 68 .

12. See Meltem Müftüler, Turkey's Relations with a Changing Europe (Manchester, Manchester University Press, forthcoming).

13. Henri Barkey, 'Turkey's Kurdish dilemma', Survival, 35(4), 1993, page 66.

14. David McDowall, The Kurds: A Nation Denied (London, Minority Rights Group, 1992), page 52.

15. Briefing, 8-15 May 1995, issue 1040 , page 3.

16. TBMM General Sekreterligi, Meclis Tutanaklari-Turkish Grand National Assembly General Secretariat, Assembly Records, March 1995, no 40.

17. Briefing, 27 March 1995, issue 1034, page 10.

18. The Wall Street Journal, Europe, 23 March 1995. 
19. Robins, op cit, reference 9 , page 87 .

20. Ali Ihsan Bagis, 'Water in the region: potential and prospects', in A I Bagis (editor), Water as an Element of Cooperation and Development in the Middle East (Ankara, Hacettepe University, 1994), page 24.

21. Erol Manisali (editor), Turkey's Place in the Middle East (Instanbul, Middle East Business and Banking Publications, 1989), page 70 .

22. George Gruen, 'International regional cooperation', in Bagis (editor), op cit, reference 20, page 263.

23. The Economist, 'The Survey of the Arab World', 12 May 1990, page 10.

24. Robins, op cit, reference 9, page 99 .

25. Jeremy Salt, 'Nationalism and the rise of Muslim sentiment in Turkey', Middle Eastern Studies, $37(1), 1995$ page 22.

26. Mango, op cit, reference 1, page 81 .

27. Salt, op cit, reference 25 , page 24 .

28. Mehmet Ögutçü, 'Islam and the West: can Turkey bridge the gap', Futures, 26(8), 1994, page 814.

29. M Müftüler, 'Turkey: A new player in Middle Eastern Politics', Mediterranean Quarterly, 6(4), Fall 1995, pages $110-120$.

30. As quoted in William Hale, 'Turkish foreign policy after the cold war', paper presented to Eurames conference, University of Warwick, 8-11 July 1993, footnote no 26, page 7 .

31. Mango, op cit, reference 1 , page 111

32. Hale, op cit, reference 30 , page 6 .

33. Claire Spencer, Turkey between Europe and the Middle East (London, Wilton Park papers, no 72, 1993), page 4 .

34. Cumhuriyet, Turkish Daily, 4 May 1995.

35. Stuart Eizenstaat's (the US ambassador to the EU) declaration as reported by Hurriyet, Turkish Daily, 2 June 1995.

36. Warren Christopher's speech in Madrid on US-EU corporation, as reported by Milliyet, Turkish Daily, 4 June 1995. 